\title{
Giant intrathoracic benign tumors: more threat than a challenge
}

\author{
C Tunea $^{1 *}$, O Burlacu², V Voiculescu 1 , G Cozma ${ }^{1}$, I Miron ${ }^{1}$, I Petrache ${ }^{1}$, A Nicodin² \\ From 23rd World Congress of the World Society of Cardio-Thoracic Surgeons \\ Split, Croatia. 12-15 September 2013
}

\section{Background}

Giant benign intra-thoracic tumors are very rare. The symptoms are non-specific, the imagistic is impressive, though the surgical ablation and the postoperative outcome are simple.

\section{Methods}

We reviewed retrospectively the charts of 16 patients, admitted between 2001 and 2012, aged 16 and 68 years. The diagnostic was based on imagistic study. We used open surgery from the beginning. We analyzed average with standard deviation for age, postoperative in hospital stay, correlation between the size and hospital stay, age and hospital stay, age and tumor size.

\section{Results}

The mean age was $42,6 \pm 16,4$ years, with male/female ratio of 0.77 . The mean postoperative hospital stay was $8,5 \pm 2,52$ days and the correlation between tumor size and hospital stay was 0.005 . The mean size of the tumors was $13.31 \pm 5,4 \mathrm{~cm}$. Correlation between age and tumor size 3.319 and between age and hospital stay 0.032 . We performed complete resection via postero-lateral approach with active suction. With the exception of one case with slow lung re-expansion (tumor over $20 \mathrm{~cm}$ ) we recorded no postoperative morbidity.

\section{Conclusions}

Although the preoperative imagistic aspects of this pathology are very impressive, the technique represents virtually no challenge for the surgeon.

\footnotetext{
* Correspondence: calin.tunea@gmail.com

'Department of Thoracic Surgery, Emergency Municipal Hospital, Timisoara, Romania

Full list of author information is available at the end of the article
}

Authors' details

${ }^{1}$ Department of Thoracic Surgery, Emergency Municipal Hospital, Timisoara, Romania. ${ }^{2}$ University of Medicine, Timisoara, Romania.

Published: 11 September 2013

doi:10.1186/1749-8090-8-S1-0233

Cite this article as: Tunea et al: Giant intrathoracic benign tumors: more threat than a challenge. Journal of Cardiothoracic Surgery 2013 8(Suppl 1): O233.
Submit your next manuscript to BioMed Central and take full advantage of:

- Convenient online submission

- Thorough peer review

- No space constraints or color figure charges

- Immediate publication on acceptance

- Inclusion in PubMed, CAS, Scopus and Google Scholar

- Research which is freely available for redistribution
() Biomed Central

\section{Biomed Central}

